OPEN ACCESS

Edited by:

Weien Yuan,

Shanghai Jiao Tong University, China

Reviewed by:

Sudarshan Singh Rathore,

SASTRA University, India

Shishir Shetty,

University of Sharjah, United Arab

Emirates

*Correspondence:

Gopal Nath

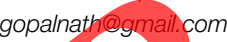

Specialty section

This article was submitted to

Translational Pharmacology,

a section of the journal

Frontiers in Pharmacology

Received: 09 October 2020

Accepted: 22 February 2021

Published: 12 April 2021

Citation:

Gangwar M, Rastogi S, Singh $D$,

Shukla A, Dhameja N, Kumar D, Kumar $R$ and Nath $G$ (2021) Study on

the Effect of Oral Administration of Bacteriophages in Charles Foster Rats

With Special Reference to

Immunological and Adverse Effects.

Front. Pharmacol. 12:615445.

doi: 10.3389/fphar.2021.615445

\section{Study on the Effect of Oral} Administration of Bacteriophages in Charles Foster Rats With Special Reference to Immunological and Adverse Effects

\author{
Mayank Gangwar ${ }^{1}$, Sonam Rastogi ${ }^{1}$, Digvijay Singh ${ }^{1}$ Alka Shukla , Neeraj Dhameja ${ }^{2}$, \\ Deepak Kumar ${ }^{1}$, Rajesh Kumar ${ }^{1}$ and Gopal Nath ${ }^{1 *}$ \\ ${ }^{1}$ Viral Research and Diagnostic Laboratory, Faculty of Mediche, Department of Microbiology, Institute of Medical Sciences, \\ Banaras Hindu University, Varanasi, India, ${ }^{2}$ Department of Pathology, Institute of Medical Sciences, Banaras Hindu University, \\ Varanasi, India
}

Numerous pre-clinical and clinical studies have recently demonstrated the significant role of phage therapy in treating multidrug-resistant bacterial infections. However, only a few researchers have focused on mopitoring the phage-mediated adverse reactions during phage therapy. Besides adverse reactions, immunological response after short- and longterm oral administration of bacteriophages is also lacking. In this study, we administered the bacteriophages orally against Klebsiella pneumoniae XDR strain in dosages of $10^{15} \mathrm{PFU} / \mathrm{ml}$ and $\mathrm{a} 10^{20} \mathrm{PFU} / \mathrm{ml}$ (still higher) to Charles Foster rats as a single dose (in acute toxicity study) and daily dosage for 28 days (in sub-acute toxicity study). One milliliter suspension of bacteriophages was administered through the oral gavage feeding tube. No adverse effect was observed in any of the experimental as well as in the control animals.Further, an insignificant change in food and water intake and body weight was observed throughout the study period compared with the control group rats. On the 28th day of phage administration, blood was collected to estimate hematological, biochemical, and cytokines parameters. The data suggested no difference in the hematological, biochemical, and cytokine profile compared to the control group. No significant change in any of the treatment groups could be observed on the gross and histopathological examinations. The cytokines estimated, interleukin-1 beta (IL-1ß), IL4, IL-6, and INF-gamma, were found within the normal range during the experiment. The results suggested no adverse effect, including the severe detrimental impact on oral administration of high $\left(10^{15} \mathrm{PFU} / \mathrm{ml}\right)$ and very high dose $\left(10^{20} \mathrm{PFU} / \mathrm{ml}\right)$ of the bacteriophages cocktail. The high and long-term oral administration of bacteriophages did not induce noticeable immunological response as well.

Keywords: oral, adverse effect, cytokines, Klebsiella pneumoniae, bacteriophage therapy 


\section{INTRODUCTION}

The emergence of multi-drug resistant bacteria has forced humankind to look for alternatives to antibiotics. In the recent time alternative approaches have focused on the development of different biologicals that includes 1) passive immunization with pathogen-specific immunoglobulin preparations, 2) induction of a pathogen-specific memory response through vaccination, 3) immune-stimulatory agents leading to potentiation of host immune response facilitating clearance of the extracellular and intracellular infecting microbe, and 4) elimination of pathogenic bacteria by using lytic bacteriophages (Zumla et al., 2016; Luepke et al., 2017). These bacteriophages (or phages) infect and promote bacterial lysis via a multi-step process of replication. As these bacterial viruses are specific to bacteria, no activity has been reported against animal or plant cells. Similar to all viruses, phages are metabolically inert in its extracellular form, and they are ubiquitous (Huff et al., 2005).

Various scientific reports suggest that most of the animal viruses and their components are the potent activators of innate as well as acquired immune responses resulting in an increased cytokine, chemokine, reactive oxygen species (ROS) production in humans and animals. These immune responses are mostly due to the viral proteins that stimulate the pro/anti-inflammatory cytokines and ROS production by immune cells (Thannickal and Fanburg, 2000). Some viral proteins such as glycoprotein gp350 and latent membrane protein 1 (LMP-1) from Epstein-Barr virus, showed strong immune expression and also maintains their proinflammatory activity by increasing production of interleukin1beta (IL-1 $\beta$ ), tumour necrosis factor-alpha (TNF-1 $\alpha$ ), IL-6, IL 10 or IL-8 (Mogensen and Paludan, 2001). Similarly, avian influenza A $(\mathrm{H} 5 \mathrm{~N} 1)$ causing severe respiratory disease in humans reported with immune response by increasing inflammatory cytokine and chemokine production (de Jong et al., 2006; Lam et al., 2011).

The efficacy of phage therapy has been proved through preclinical and clinical studies administered orally or parenterally (Capparelli et al., 2007; Mann 2008; Debarbieux et al., 2010; Gavel et al., 2019; Gupta et al., 2019; Nath et al., 2019; Patel et al., 2019). Phages are protein in nature that might induce immunological response as well as induce non-immunological adverse/toxic effects, as mentioned above in the mammalian hosts. Currently, substantial interest has emerged in the field of bacteriophage therapy to be used as anti-bacterial agents. Phages may be introduced to the human body through oral and parenteral routes. The oral route is primarily supposed to eradicate the implicated pathogens present in the gut. Further, if the bacterial pathogens colonizing the gut causing intestinal or extra-intestinal diseases such as diarrhea, dysentery, food poisoning, typhoid, acid peptic diseases, obesity, auto-brewery syndrome, non-alcoholic fatty liver disease, ulcerative colitis, irritable bowel syndrome, other autoimmune disorders etc., if identified in future can be eradicated through oral bacteriophages (Morgan et al., 2012; Rajpal \& Brown, 2013; Kishor et al., 2016; Chaturvedi and Nath, 2018; Ganeshan and Hosseinidoust, 2019; Rouse et al., 2020). But, the questions are that: 1) Is oral bacteriophage therapy safe to human health? 2) Are the bacteriophages able to induce adverse immunological responses? If yes, it is only a small dosage or larger dosages cause adverse effects or immunological responses.

Reports on non-immunological and immunological adverse impacts of oral bacteriophages are scarce and yet to be documented especially if high dosages are used for a long duration (Górski et al., 2006; Górski and Weber-Dabrowska, 2005; Górski et al., 2012). Therefore, the present study, was planned to explore the adverse effect of short- and long-term oral administration of high dosages of bacteriophage on rats.

\section{MATERIALS AND METHODS}

\section{Chemicals and Reagents}

Phosphate buffer saline (PBS, molecular biological grade) was purchased from Sigma-Aldrich (St. Louis, MO). Chloroform and magnesium sulphate were procured from Merck, India. MüllerHinton agar (MHA), Polyethylene glycol (PEG), agar powder (bacteriological grade), and Tris-hydrochloride AR were obtained from HiMedia Laboratories Pvt. Ltd. India. Sodium chloride laboratory-grade was procured from S D Fine-Chem Limited, India. Gelatin was purchased from BDH Laboratory, Glaxo Laboratories India Limited. All other chemicals used in the present study were of analytical grade available in India.

\section{Laboratory Animaís}

A total number of 18 healthy male and female inbred CharlesFoster albino rats (180-220 g) were used in the experiment. All the animals were procured from the Central Animal House (Reg.no.542/02/ab/CPCSEA), Institute of Medical Sciences, Banaras Hindu University, Varanasi, India. All the animals during the experiment were given standard rodent diet procured from M/s. Golden feeds, Mehrauli, New Delhi, India. All the healthy pathogen-free animals were housed in polypropylene cages in the departmental animal house of Microbiology. Food and water were provided ad libitum. The rats were kept at a controlled temperature of $22 \pm 3^{\circ} \mathrm{C}$; humidity of $40-56 \%$ and light and dark cycles of $12 \mathrm{~h}$ each for one week before and during the experiments. Animal experimental manipulations and postoperative care were conducted according to the Institute for Laboratory Animal Research, US guidelines for the Care and Use of Laboratory Animals. Animals were anesthetized with pentobarbitone $(35 \mathrm{mg} / \mathrm{kg}$ body weight) intraperitoneally at the end of the experiment for collection of blood through retro-orbital veins. The animals were acclimatized for 5 days before the experiment, and each rat was accessed once daily for clinical signs, behavior, morbidity and mortality. All the animals were allowed to breathe spontaneously during the surgery.

\section{Bacterial Strain, Isolation, and Identification of Klebsiella pneumoniae}

A clinical strain of Klebsiella pneumoniae was isolated and collected from the patients admitted to the intensive care unit of a tertiary level university hospital of Banaras Hindu University. Mueller Hinton Agar media was used for isolation of the bacteria. 
The isolated bacteria were confirmed on the basis of colony morphology, Gram staining, biochemical, and molecular technique using $K$. pneumoniae specific primers, i.e., KP16 F' GCAAGTCGAGCGGTAGCACAG (nucleotide position 50-70) and KP16 R' CAGTGTGGCTGGTCATCCTCTC (nucleotide position 279-309) with $260 \mathrm{bp}$ product. The PCR cycle used for amplification was $95^{\circ} \mathrm{C}$ for $3 \mathrm{~min}$ followed by 28 cycles of $95^{\circ} \mathrm{C}$ for $45 \mathrm{~s}, 58^{\circ} \mathrm{C}$ for $45 \mathrm{~s}, 72^{\circ} \mathrm{C}$ for $1 \mathrm{~min}$, and a final extension at $72^{\circ} \mathrm{C}$ for $5 \mathrm{~min}$. Antimicrobial susceptibility test (AST) of $K$. pneumoniae was done by using the standard Bauer-Kirby disc diffusion method. The size of inhibition zones was recorded and interpreted according to the Clinical and Laboratory Standards Institute breakpoint Guidelines (CLSI guideline 2018). On antibiotic sensitivity evaluation, the strain was found to be an extensively drug-resistant (XDR). The strain was tested for its susceptibility to gentamicin (GEN, $10 \mu \mathrm{g}$ ), amikacin (AK, $30 \mu \mathrm{g}$ ), netilmicin-sulphate (NET, $30 \mu \mathrm{g})$, carbenicillin (CB, $100 \mu \mathrm{g})$, piperacillin/tazobactam (PTZ, 100/10 $\mu \mathrm{g}$ ), ceftriaxone (CTR, $30 \mu \mathrm{g})$, ceftazidime (CAZ, $30 \mu \mathrm{g})$, cefepime (CPM, $30 \mu \mathrm{g})$, imipenem (IPM, $10 \mu \mathrm{g}$ ), meropenem (MRP, $10 \mu \mathrm{g}$ ), ertapenem (ETP, $10 \mu \mathrm{g}$ ), ciprofloxacin (CIP, $5 \mu \mathrm{g}$ ), levofloxacin (LE, $5 \mu \mathrm{g}$ ), ofloxacin (OF, $5 \mu \mathrm{g})$, co-trimoxazole (COT, $25 \mu \mathrm{g})$, chloramphenicol (C, $30 \mu \mathrm{g}$ ), fosfomycin (FO $200 \mu \mathrm{g}$ ) and azithromycin (AZM, $15 \mu \mathrm{g}$ ). The sensitivity for colistin and polymyxin was tested by broth dilution technique.

\section{Source, Sample Collection, and Processing of Water Samples}

The water samples were collected aseptically from different wate sources (river, ponds, and sewer). One liter volume of water was collected in the sterile bottle from one foot below the surface. Further, the samples were immediately transferred to the laboratory and were processed as per the method described by Gupta et al. (2016) with slight modifications. Before treatment with chloroform, the samples were centrifuged for $10778 \times \mathrm{g}$ for $10 \mathrm{~min}$ in a refrigerated centrifuge (Remi CPR-24 plus).

\section{Isolation and Purification of Specific Bacteriophages}

Bacteriophage isolation was performed using double agar overlay method with slight modification against this strain from different water sources (river, ponds, and sewer) (Gupta et al., 2016). Bacterial lawn culture $\left(10^{8} \mathrm{CFU} / \mathrm{ml}\right.$ suspensions) was made and was incubated for $2 \mathrm{~h}$. Water specimens from different water bodies were treated with $1 \%$ chloroform $(v / v)$ for $20 \mathrm{~min}$ and centrifuged for $10 \mathrm{~min}$ at $10778 \times \mathrm{g}$, which was dropped over the bacterial lawn and the plates were incubated for overnight at $37^{\circ} \mathrm{C}$. Next day the bacteriolytic activity was noticed in the lawn. Bacteriophages were harvested from the plate using $~ 3 \mathrm{ml} \mathrm{TMG}$ (Tris- $\mathrm{HCl}$, magnesium sulphate, gelatin $\mathrm{pH}$ 7.4) buffer and centrifuged at $10778 \times g$ for $15 \mathrm{~min}$. The supernatant $(1 \mathrm{ml})$ was transferred to a $1.5 \mathrm{ml}$ micro-centrifuge tube. Soft agar overlay method was used to get isolated plaques. The process of the soft agar overlay method was repeated till the uniform size and shape of the plaques were observed.
For increasing the number of the bacteriophage, a single plaque was picked up in $1 \mathrm{ml}$ of TMG buffer. The lawn culture of the $K$. pneumoniae was prepared on $\mathrm{MH}$ agar and incubated for $4 \mathrm{~h}$ to have the bacteria in log phage. The harvested plaque suspension was poured on the whole Petri plate (90 MM) and incubated overnight at $37^{\circ} \mathrm{C}$. The cleared lawn was again harvested in $3 \mathrm{ml}$ of TMG buffer. The Roux bottle containing MH agar was seeded with the host bacteria and brought to the log phase as described earlier. The $3 \mathrm{ml}$ phage harvest was flooded over this lawn and incubated overnight. Next day about $15 \mathrm{ml}$ of TMG was used to harvest the phage was inoculated on six Roux bottle with log phage lawn of the bacterium. After washing each of the Roux bottle yield, the harvest was treated with $1 \%$ chloroform for $10 \mathrm{~min}$ to lyse the intact bacteria. Each of the six harvests in separate Falcon tube was subjected to centrifugation at $10778 \times g$ for $15 \mathrm{~min}$. The supernatant was collected from each of the tubes and subjected to membrane dialysis. The supernatant was loaded in membrane dialysis bags and suspended in a solution containing $25 \%$ PEG-8000 and $2.5 \mathrm{M} \mathrm{NaCl}$ solution in a big flask at $4^{\circ} \mathrm{C}$ for overnight. Two more washing of the phage suspension in the same bag was done by adding fresh PBS ( $\mathrm{pH} 7.2$ ) to the dialysis membrane tube and 25\% PEG-8000 and $2.5 \mathrm{M} \mathrm{NaCl}$ solution in the outer container. After the third dialysis, all the six thick phage suspension from the dialysis bag was harvested with $1 \mathrm{ml}$ volume/tube in one membrane bag and made up to $15 \mathrm{ml}$ with PBS and again dialyzed with 25\% PEG8000 and $2.5 \mathrm{M} \mathrm{NaCl}$ solution overnight at $4^{\circ} \mathrm{C}$. The thick yellowish colour fluid was harvested with $6 \mathrm{ml}$ of TMG. The plaque counting was carried out by using the soft agar overlay method (Kropinski et al., 2009; Mishra and Nath, 2020; Patel 2019). The above in-house method gave the yield of about $10^{25} \mathrm{PFU} / \mathrm{ml}$, which was diluted further to achieve $10^{20}$ and $10^{15} \mathrm{PFU} / \mathrm{ml}$ concentration of the bacteriophage.

The endotoxin level of the harvested phage preparations was determined by using Thermo Scientific ${ }^{\mathrm{TM}}$ Pierce $^{\mathrm{TM}}$ LAL Chromogenic Endotoxin Quantitation Kit ELISA based kit, according to the manufacturer's instructions. Before performing the test, phage samples and standards of the kit were diluted and were incubated as per instructions. Finally, the color signal was measured using spectrophotometer absorbance at $405-410 \mathrm{~nm}$ on a plate reader. The readings were relatively calculated for the presence of endotoxins and defined as the endotoxin content per phage titer (EU/PFU) (Szermer-Olearnik and Boratyński, 2015).

\section{Experimental Procedure and Acute Toxicity Study (OECD, 2001) of Isolated Bacteriophages}

Charles-Foster albino rats of either sex were randomly divided into three groups of six animals (with the equal number of both male and female) in each group, which were fasted overnight. Acute toxicity study was performed as per the Organization for Economic Co-Operation and Development (OECD 423) guideline (Botham, 2002). The control (group 1) received TMG (Tris-HCl, magnesium sulphate, gelatin $\mathrm{pH}$ 7.4) buffer and served as a vehicle control group. The experimental groups 
two and three received a medium $\left(10^{15} / \mathrm{ml}\right)$ and high $\left(10^{20} / \mathrm{ml}\right)$ oral doses of pure bacteriophages, respectively. Animals were observed closely for first $4 \mathrm{~h}$, for any adverse manifestation, like increased motor activity, salivation, convulsion, coma, and death. Subsequent observations were made at regular intervals for 24-48 h. The animals were under further investigation for 2 weeks, while the number of animals died during this phase was noted.

\section{Sub-Acute Toxicity Study (OECD, 1998) of Isolated Bacteriophages}

Charles-Foster albino rats of either sex (equal number of both sexes), weighing between 180 and $220 \mathrm{~g}$ were divided into three groups. Group one, two, and three received TMG (Tris-HCl, magnesium sulphate, gelatin $\mathrm{pH}$ 7.4) buffer, medium phage concentration $\left(10^{15} / \mathrm{ml}\right)$ and high phage concentration $\left(10^{20} /\right.$ $\mathrm{ml}$ ), respectively. The doses were administered orally once daily by oral gavage in the volume of $10 \mathrm{ml} / \mathrm{kg}$ bodyweight for 28 consecutive days according to the OECD test guideline 407 (Institóris et al., 1998). During the treatment period, animals were observed daily for general behaviour, body weight, food and water intake, hematological profile, liver (total protein, albumin, globulin, total bilirubin, alkaline phosphatase, SGOT, and SGPT) and renal (urea and creatinine) function tests. The weight of all the major organs like liver, kidney, testes/ovaries and adrenal glands was recorded at the end of 28 days of treatment. Histology of all the major organs such as liver, lungs, kidney, heart, spleen, stomach, testes/ovaries, adrenal, and pancreas was also carried out to study any cellula changes after bacteriophage therapy.

\section{Estimation of Hematological and Biochemical Parameters}

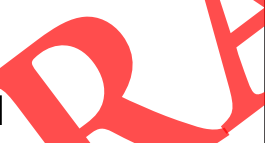

At the end of the experiment, blood was collected from the retrobulbar plexus and cardiac puncture using heparinized and non-heparinized capillary tubes. Blood samples in the nonheparinized capillary tube were kept in plain red vials to collect serum, which was further stored for biochemical analysis. However, the heparinized tube's blood was directly subjected to the estimation of various hematological parameters using a standard instrument. The various hematological parameters such as hemoglobin $(\mathrm{Hb})$, red blood corpuscle (RBC), packed cell volume (PCV), mean corpuscular volume $(\mathrm{MCV})$, mean corpuscular hemoglobin $(\mathrm{MCH})$, mean corpuscular hemoglobin concentration $(\mathrm{MCHC})$, platelets, total leukocyte count and differential leukocyte count were analyzed with blood samples among all the groups. In addition, samples were also subjected to biochemical estimation for the level of magnesium, blood urea nitrogen (BUN), creatinine, uric acid, calcium, phosphorus, potassium, sodium, chloride ion concentration, aspartate transaminase (AST), alanine transaminase (ALT), alkaline phosphate (ALP), creatinine, blood glucose, total protein, and total cholesterol and bilirubin analysis in serum sample using Hematology analyzer (Abbott Model-CD-3700).

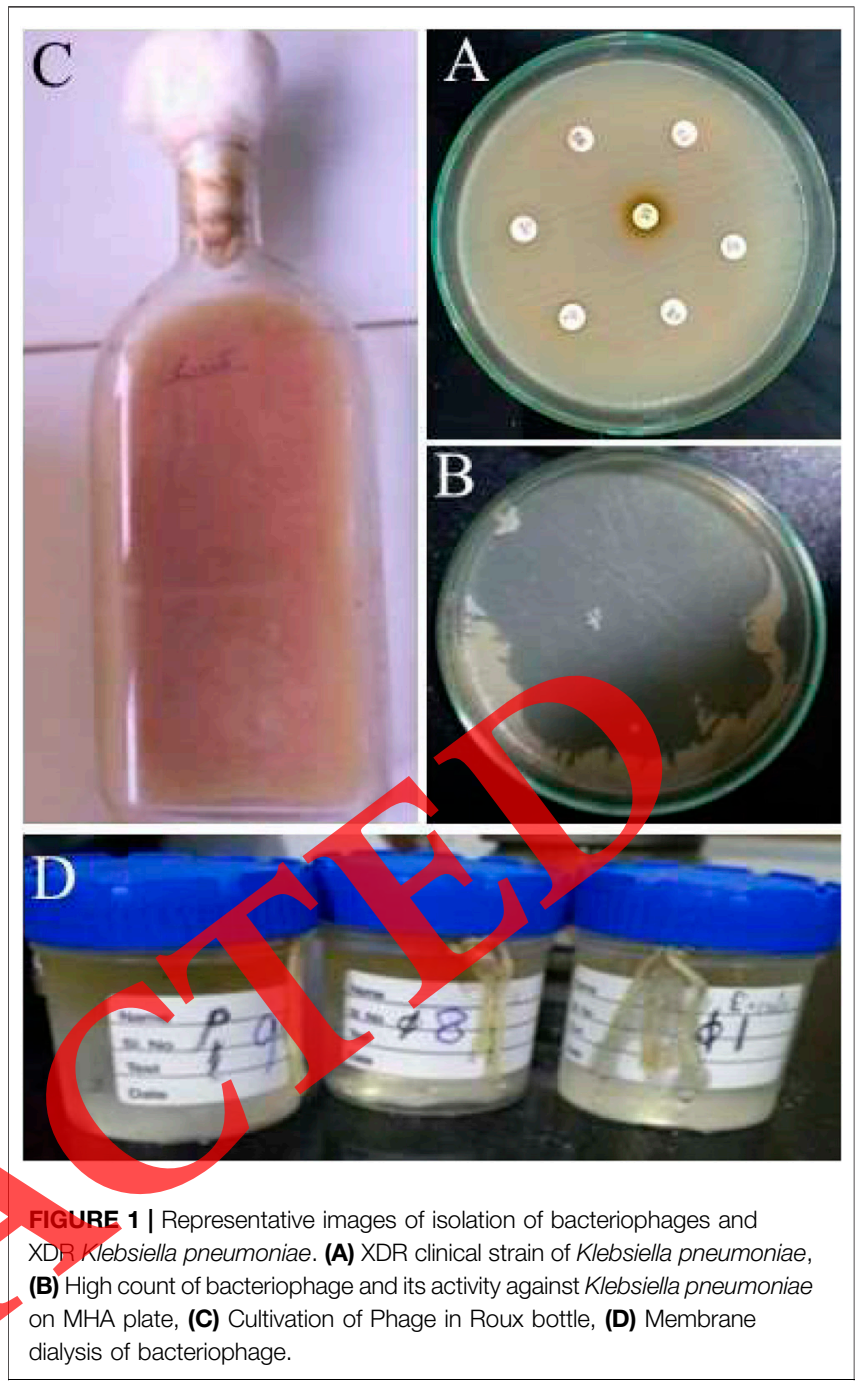

\section{Estimation of Pro-and Anti-Inflammatory Cytokines}

The levels of pro and anti-inflammatory cytokines were estimated in all the animals at the end of the experiment in each group, using ELISA assay. Interleukin-1 beta (IL-1 $\beta$ ), IL-4, IL-6, and INF-gamma were tested from serum/plasma using standard ELISA assay procedure described by the manufacturer. In brief, $\sim 50 \mu \mathrm{l}$ of respective assay diluent was added to each well as per the specific kit standards in different concentrations and samples were pipetted into the wells followed by incubation for $90 \mathrm{~min}$ at $37^{\circ} \mathrm{C}$. After washing away any unbound substances for a total of five times, the biotin-labelled antibody was added and incubated for at $37^{\circ} \mathrm{C}$ for $60 \mathrm{~min}$. Further, after washing, the HRP-Streptavidin conjugate working solution was added and incubated at $37^{\circ} \mathrm{C}$ for $30 \mathrm{~min}$. After washing, TMB substrate was added in all the wells and incubated at $37^{\circ} \mathrm{C}$ for $15-30 \mathrm{~min}$. After incubation, the reaction was stopped by adding respective stop solution in each well. Immediately after addition of stop solution, optical density (O.D.) was observed at $450 \mathrm{~nm}$ in a microtiter plate using Multiskan ${ }^{\mathrm{TM}}$ FC Microplate Photometer (Thermo Scientific ${ }^{\mathrm{TM}}$, United States). The detailed procedures for calculation of respective cytokines 

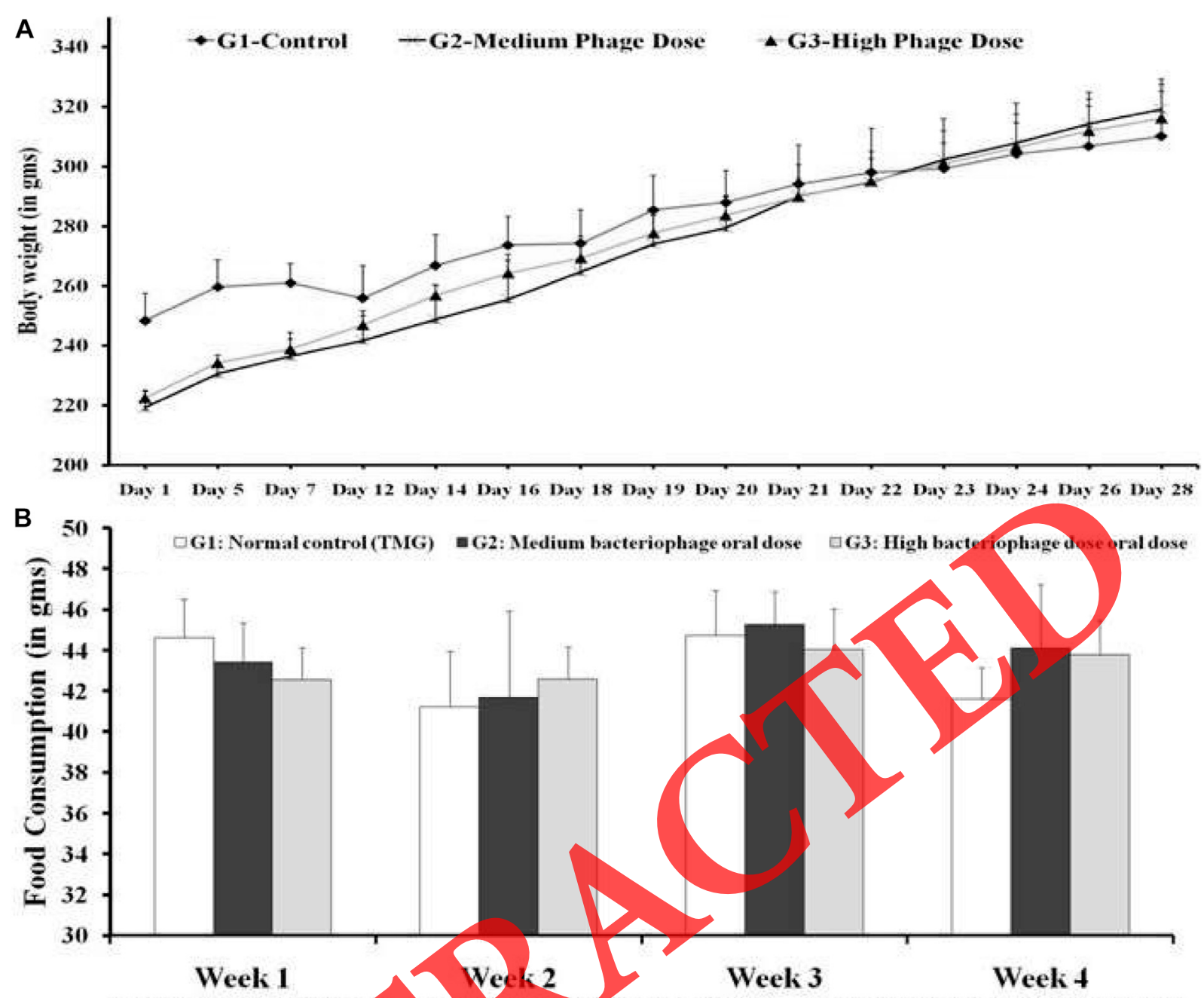

C 40, G1: Normal control (TMG) G2; Medium backeriophage oral dose $\square$ G3: High bacteriophage dose oral dose

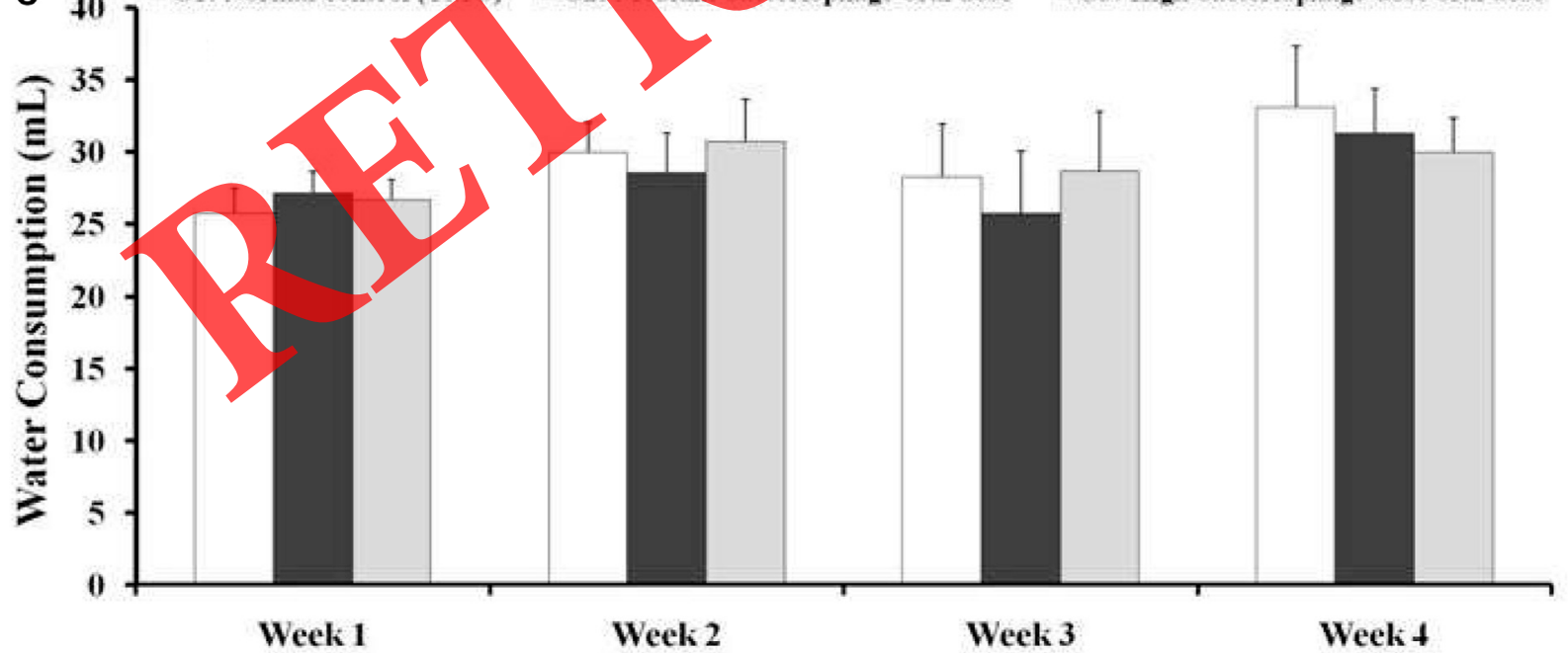

FIGURE 2 | (A) Body weights analysis (B) Average daily feed consumption and (C) Water consumption (in ml). G1: Control group animals received TMG (Tris-HCl, magnesium sulfate, gelatin $\mathrm{pH}$ 7.4) buffer; G2: Animals received oral administration of the medium dose of bacteriophages (10 ${ }^{15}$ PFU/ml); and G3: High oral dose of bacteriophages $\left(10^{20} \mathrm{PFU} / \mathrm{ml}\right)$. All the values are presented as mean $\pm \mathrm{SEM}(n=6)$. No significant difference could be found among the different groups $(p>0.05)$. 
TABLE 1 | Effect of bacteriophages in sub-chronic toxicity assay for the organ to body weight ratio (in percentage).

\begin{tabular}{|c|c|c|c|c|c|c|c|c|}
\hline Group (G) & Liver & Lungs & Kidney & Heart & Spleen & Pancreas & Testis & Stomach \\
\hline G1 & $2.87 \pm 0.26$ & $0.65 \pm 0.05$ & $1.00 \pm 0.09$ & $0.51 \pm 0.04$ & $0.26 \pm 0.04$ & $0.56 \pm 0.07$ & $1.17 \pm 0.10$ & $0.62 \pm 0.08$ \\
\hline G2 & $2.87 \pm 0.34$ & $0.64 \pm 0.01$ & $0.97 \pm 0.05$ & $0.43 \pm 0.02$ & $0.28 \pm 0.02$ & $0.49 \pm 0.06$ & $1.16 \pm 0.12$ & $0.55 \pm 0.07$ \\
\hline G3 & $2.76 \pm 0.37$ & $0.72 \pm 0.03$ & $0.83 \pm 0.06$ & $0.44 \pm 0.02$ & $0.25 \pm 0.02$ & $0.42 \pm 0.01$ & $1.06 \pm 0.05$ & $0.65 \pm 0.01$ \\
\hline
\end{tabular}

G: Group; G1: Normal control (TMG); G2: Medium oral dose of bacteriophage (10 $15 / \mathrm{ml})$, and G3: High oral dose of bacteriophage (10 $20 / \mathrm{ml})$; All the values are presented as mean \pm SEM $(\mathrm{n}=6)$. No significant difference could be found among the different groups $(\mathrm{p}>0.05)$.

TABLE 2 | Evaluation of hematological parameters assessed after treatment with the bacteriophages in Charles Foster rats.

Parameters
Experimental treatment groups
G3

\begin{tabular}{lcr} 
Parameters & & Experim \\
\cline { 2 - 3 } & G1 & G2 \\
\hline RBC $\left(\times 10^{6} / \mu \mathrm{l}\right)$ & & $9.34 \pm 0.12$ \\
WBC $\left(\times 10^{3} / \mu \mathrm{l}\right)$ & $9.70 \pm 0.12$ & $4.51 \pm 1.86$ \\
Lymphocytes $\left(\times 10^{3} / \mu \mathrm{l}\right)$ & $4.91 \pm 1.21$ & $6.00 \pm 0.45$ \\
Monocyte $\left(\times 10^{3} / \mu \mathrm{l}\right)$ & $7.13 \pm 0.52$ & $0.51 \pm 0.09$ \\
Eosinophils $\left(\times 10^{3} / \mu \mathrm{l}\right)$ & $0.40 \pm 0.04$ & $0.16 \pm 0.00$ \\
Neutrophils $\left(\times 10^{3} / \mu \mathrm{l}\right)$ & $0.15 \pm 0.00$ & $1.06 \pm 0.02$ \\
Hb $(\mathrm{gm} / \mathrm{dl})$ & $1.42 \pm 0.19$ & $16.75 \pm 0.41$ \\
PCV $(\%)$ & $16.75 \pm 0.41$ & $39.18 \pm 0.47$ \\
MCV (fl) & $39.18 \pm 0.47$ & $54.90 \pm 1.78$ \\
MCH (pg) & $54.90 \pm 1.78$ & $17.13 \pm 0.28$ \\
MCHC (gm/dl) & $17.13 \pm 0.28$ & $31.73 \pm 0.42$ \\
Platelet count (thousand $\left./ \mathrm{mm}^{3}\right)$ & $31.73 \pm 0.42$ & $682.25 \pm 12.49$
\end{tabular}

Normal Ref. Range

Alemán et al. 1998

\begin{tabular}{cc} 
G3 & $\begin{array}{c}\text { Normal Ref. Range } \\
\text { Alemán et al. 1998 }\end{array}$ \\
$8.94 \pm 0.14$ & $7.27-9.65$ \\
$4.98 \pm 2.20$ & $1.96-8.25$ \\
$7.99 \pm 0.31$ & $1.41-7.11$ \\
$0.63 \pm 0.14$ & $0.03-0.18$ \\
$0.17 \pm 0.03$ & $0.01-0.16$ \\
$2.50 \pm 0.45$ & $0.22-1.57$ \\
$16.75 \pm 0.41$ & $13-18$ \\
$39.18 \pm 0.47$ & $34-42$ \\
$54.90 \pm 178$ & $48.5-55.0$ \\
$\$ 7.13 \pm 0.28$ & $17.5-22.0$ \\
$31.73 \pm 0.42$ & $32.0-43.0$ \\
$682.25 \pm 12.49$ & $450-750$ \\
& \\
\hline
\end{tabular}

G1: Normal control (TMG); G2: A medium oral dose of bacteriophage $\left(10^{15} \mathrm{PFU} / \mathrm{ml}\right)$, and G3: High oral $(n=6)$. No significant difference could be found among the different groups $(p>0.05)$. The normal ref animal Clinical Laboratory Parameters.

concentration with respect to standards were followed as per the manufacturer's instructions (Immunotag ${ }^{\mathrm{TM}}$ ELISA Kits).

\section{Measurement of Relative Organ Weight and Histopathological Examination}

At the end of the experiment, rats were dissected, and the wholeliver, lungs, kidney, heart, spleen, stomach, testes/ovaries, adrenal, and pancreas were excised, freed of fat, blotted dry with clean tissue paper, and then weighed. The organ to body weight ratio was estimated by comparing the weight of each organ with the final body weight of each rat. All the defined samples were placed in $10 \%$ neutral buffered formalin for histopathological examination as per standard protocol followed by tissue embedded in paraffin sections, stained with hematoxylin and eosin, and were examined histological changes. Two slides were prepared with $3-6 \mu \mathrm{M}$ thick tissue sections from all the blocks. One slide was stained with hematoxylin and eosin stain for routine histopathological examination. All the sections were stained with the help of Automatic Linear Slide Stainer (Medimeas, MSS-AS) with hematoxylin and eosin staining method as per standard protocol. The fixed slides were analyzed under an inverted microscope (Nikon ECLIPSE Ts2).

\section{Estimation of Body Weight, Water and Food Intake}

All the experimental animals were subjected to measurement of body weight and food intake before oral dosing of the bacteriophages daily. Briefly, the measurement of daily feed supply (in gms) and the left-over feed by the following day was recorded, and the difference was taken as the daily feed intake by the animal. The data was noted, and average feed and water intake were computed for every three days of the experimental period.

\section{Clinical Sign}

Abnormal behavior in animals was recorded with the time of onset and disappearance. In case, any animal found in a moribund condition or enduring signs of severe distress was humanely euthanized.

\section{Statistical Analysis}

All the data obtained were presented as the mean \pm standard error of the mean (SEM) using Sigma-Plot statistical software (Version 11.0). The comparisons involving more than two groups were performed using one-way analysis of variance (ANOVA) followed by post-hoc analysis by Dunnett's test. The $p \leq 0.05$ was considered as statistically significant.

\section{RESULTS}

\section{Isolation and Characterization of the Bacterial Host Strain}

K. pneumoniae bacterial strain from the clinical source was isolated and tested for susceptibility to different phages. The 
TABLE 3 | Effect of treatment with the bacteriophages on the level of serum biochemical analysis in Charles foster rats.

\begin{tabular}{lcc}
\hline Parameters & & Experin \\
\cline { 2 - 3 } & G1 & G2 \\
\hline TB (mg/dl) & & $0.09 \pm 0.02$ \\
SGOT (U/L) & $0.14 \pm 0.02$ & $180.90 \pm 12.26$ \\
SGPT (U/L) & $146.88 \pm 8.75$ & $37.38 \pm 1.21$ \\
ALP (U/L) & $53.13 \pm 8.13$ & $159.59 \pm 11.76$ \\
CK-MB (U/L) & $164.25 \pm 24.09$ & $226.40 \pm 18.19$ \\
TP (g/dl) & $185.00 \pm 26.89$ & $7.11 \pm 0.33$ \\
A (g/dl) & $6.21 \pm 0.05$ & $3.78 \pm 0.15$ \\
G (g/dl) & $2.70 \pm 0.39$ & $3.05 \pm 0.02$ \\
A/G ratio & $2.96 \pm 0.04$ & $1.10 \pm 0.02$ \\
Creatinine (mg/dl) & $1.10 \pm 0.02$ & $0.68 \pm 0.02$ \\
Uric acid (mg/dl) & $0.58 \pm 0.10$ & $0.98 \pm 0.04$ \\
Blood urea (mg/dl) & $0.81 \pm 0.06$ & $40.40 \pm 3.17$ \\
Calcium (mg/dl) & $29.53 \pm 2.55$ & $10.51 \pm 0.07$ \\
Phosphorus (mg/dl) & $9.76 \pm 0.37$ & $7.85 \pm 0.65$ \\
Na+ (mmol/L) & $6.71 \pm 0.58$ & $134.68 \pm 4.06$ \\
K+ (mmol/L) & $137.95 \pm 2.99$ & $6.15 \pm 0.53$ \\
Cl- (mmol/L) & $7.67 \pm 1.61$ & $96.68 \pm 2.37$ \\
Glucose (mg/dl) & $99.95 \pm 5.54$ & $149.48 \pm 8.56$ \\
TC (mg/dl) & $111.25 \pm 5.48$ & $117.46 \pm 6.75$ \\
Triglyceride (mg/dl) & $88.52 \pm 5.34$ & $109.08 \pm 10.13$ \\
HDL (mg/dl) & $97.38 \pm 7.54$ & $73.11 \pm 5.11$ \\
LDL (mg/dl) & $65.17 \pm 2.84$ & $14.16 \pm 1.03$ \\
VLDL (mg/dl) & $15.39 \pm 1.88$ & $28.00 \pm 7.05$
\end{tabular}

Experimental treatment groups

G3

Normal Ref. Range

Alemán et al. (1998)

$\begin{array}{cc}0.12 \pm 0.01 & 0.05-0.15 \\ 186.43 \pm 21.10 & 150-190 \\ 43.37 \pm 11.66 & 60-90 \\ 148.39 \pm 13.16 & 62-230 \\ 209.75 \pm 21.88 & 162-1184 \\ 8.13 \pm 0.91 & 5.2-7.1 \\ 3.91 \pm 0.32 & 3.4-4.8 \\ 2.57 \pm 0.02 & 1.5-2.5 \\ 1.26 \pm 0.02 & 1.58-2.67 \\ 0.64 \pm 0.02 & 0.2-0.5 \\ 1.21 \pm 0.08 & 0.5-1.4 \\ 34.90 \pm 3.64 & 12.3-24.6 \\ 11.64 \pm 0.18 & 9.5-11.5 \\ 7.79 \pm 0.76 & 5.58-10.4 \\ 130.70 \pm 10.30 & 142-151 \\ 5.61 \pm 0.69 & 3.82-5.55 \\ 91.05 \pm 2.30 & 90-106 \\ 152.62 \pm 18.38 & 70-208 \\ 110.17 \pm 5.43 & 37-85 \\ 118.56 \pm 14.70 & 20-120 \\ 77.21 \pm 1.79 & 55-80 \\ 22.69 \pm 1.34 & 15-24 \\ 25.00 \pm 3.32 & 18-28\end{array}$

05-0.15

60-90

$5.2-7.1$

$3.4-4.8$

$5-2.5$

$0.5-1.4$

.3-24.6

2-5.55

$-106$

37-85

0-120

8-28

G: Group; G1: Normal control (TMG); G2: Medium oral dose of bacteriophage (10 $15 / \mathrm{ml})$, and G3: High oral dose of bacteriophage (1020/ml); No significant difference could be found among the different groups $(\mathrm{p}<0.005)$. All the values are presented as mean $\pm S E M(\mathrm{n}=6)$. No significant difference could be found among the different groups $(\mathrm{p}>0.05)$. The normal reference ranges of serum biochemical parameters were mentioned and compared as per animal Clinical Laboratory Param

clinical isolate was confirmed using the colony morphology (Figure 1A), biochemical test, and molecular method using PCR. Further, the clinical strain was tested against the selected 11 antibiotics of six different classes based on the bacterial spectrum, route of administration and type of activity to isolate the multi-drug resistant and XDR strain. Only the XDR strain was selected for further isolation of bacteriophages. The antibiotics panel was tested against the $K$. pneumoniae strains, and only XDR strain based on the tentative zone of inhibition diameter were selected using the latest 2020 CLSI guidelines. Among the tested antibiotics, only fosfomycin was found to be susceptible in disk diffusion assay with a zone of diameter of $24 \mathrm{~mm}$. Fosfomycin was effective as per CLSI listed zone diameter criteria (susceptible, $\leq 16 \mathrm{~mm}$; intermediate, $13-15 \mathrm{~mm}$; resistant, $\leq 12 \mathrm{~mm}$ ). However, other antibiotics were found to be resistant according to the zone of inhibition range. Majority of the isolates showed resistant to multiple drugs (i.e., resistance to two or more classes of the tested antimicrobials), and these were selected for bacteriophage isolation.

\section{Isolation of Bacteriophages}

Bacteriophages were isolated as per the standardized protocol described by Nath et al. 2019 (Gupta et al., 2016; Nath et al., 2019), while phage counting was done by soft agar overlay method of Nath et al. (2019). The bacteriophages specificity was tested against isolated XDR K. pneumoniae clinical strains using plaque formation by using a soft agar overlay method. The isolated phages specific to K. pneumoniae formed small and circular plaques that formed well-demarcated big plaques on the top agar plate. The phages were purified and endotoxin level using Pierce LAL Chromogenic Endotoxin Quantitation Kit and was found to be in the safe range of 0.005-0.01 EU/PFU, which was compared and found to be free from endotoxin. Further, the phage titers were determined using log dilutions of the purified phage lysate, and the resulting range of titers were $2.5 \times 10^{5} \mathrm{PFU} /$ $\mathrm{ml}$ to $5 \times 10^{20} \mathrm{PFU} / \mathrm{ml}$. These media $\left(1 \times 10^{15} \mathrm{PFU} / \mathrm{ml}\right)$ and high doses $\left(1 \times 10^{20} \mathrm{PFU} / \mathrm{ml}\right)$ of bacteriophages were selected for the acute and sub-acute toxicity assay in an animal model (Figure 1). However, the isolated bacteriophages were also tested against different host in order to check the cross-infection such as E. coli, Enterobacter cloacae, Proteus mirabilis, Salmonella Typhi, Staphylococcus aureus, Acinetobacter baumannii, Pseudomonas aeruginosa, Vibrio cholerae, Plesiomonas shigelloides, and Shigella dysenteriae.

\section{Acute Toxicity Study Observation for Behavioral Changes}

All the animals were observed for behavioral changes after oral administration of bacteriophages in respective groups. Animals under medium and high dose of bacteriophages showed behavioral changes such as slow response to external stimuli, motionlessness, prostration, and rapid breathing for 60-120 min after the first oral administration through gavage. This change in behavior might have occurred due to a strange uncomfortable experience by the rats for the first time in their life. This 


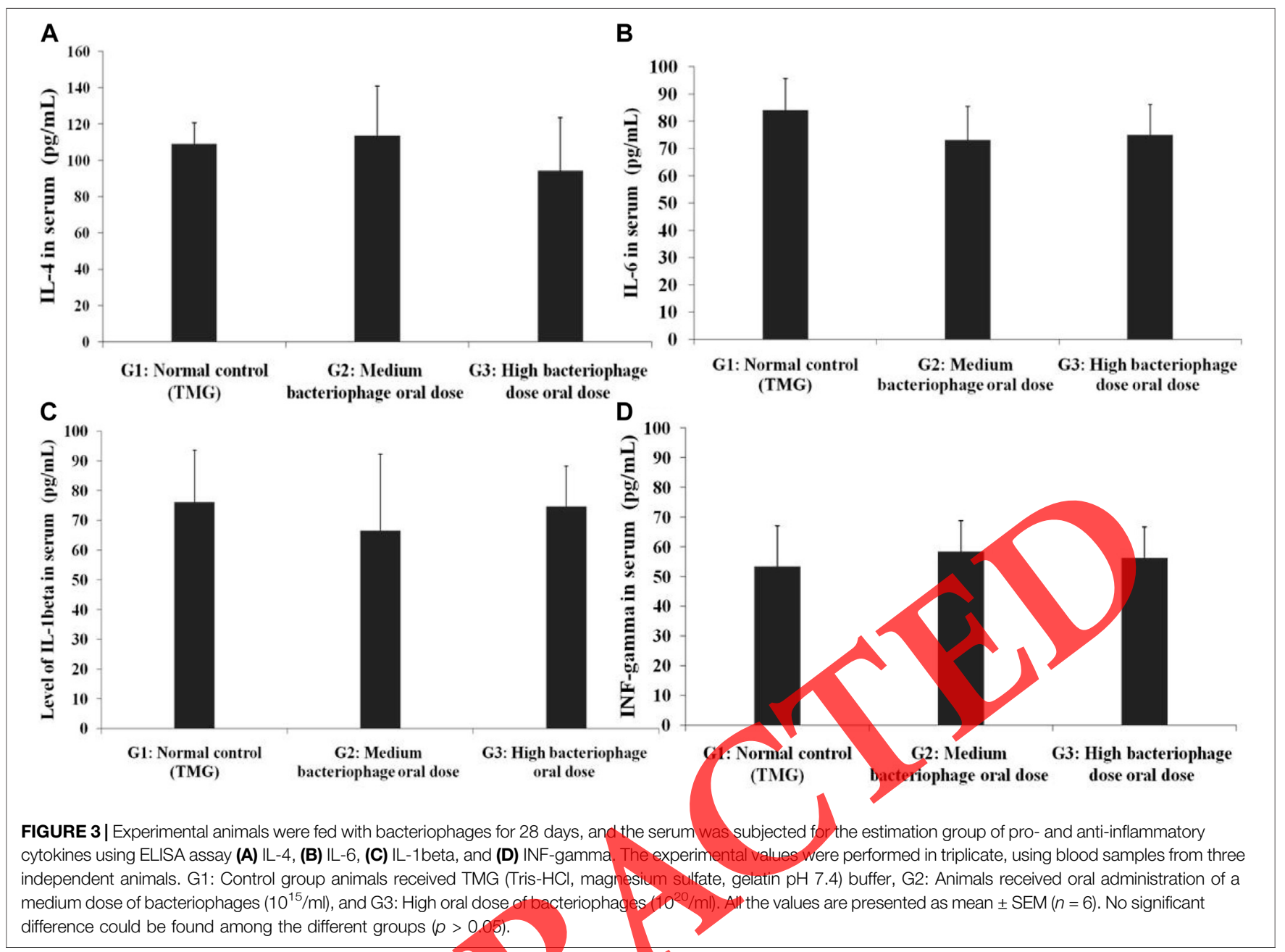

speculation is further supported by the observation that behavioral pattern in all the groups was restored to normal with further dosages up to 28 days. Thus, the no-observedadverse-effect level (NOAEL) for the oral bacteriophage dose was observed. However, after 14 days ( 2 weeks), no animal displayed any behavioral abnormality like trembling, salivation, hair loss, impairment in food and water intake, body weight, sleep, diarrhoea breathing, altered water consumption, restlessness, lethargy, postural abnormalities, or in physical appearance such as eye colour, mucous membrane, body weight, skin/fur changes, injury, as compared to the animals of the control group. One rat each died in control as well in high bacteriophage dose group after 4 days of the experiment. However, post mortem examinations revealed no macroscopic lesions in the internal organs.

\section{Sub-chronic Oral Toxicity of Bacteriophages in Rats General Behavior, Body Weight, Food, Water Intake, and Organ to Body Weight Ratio}

Isolated pure bacteriophages at medium and high concentrations were administered orally, which did not induce any visible sign in rats of both sexes. However, no lethality was recorded during the 28 days of oral bacteriophage administration. No difference in general behavior, food, and water intake was observed between the tested groups of rats. The changes in body weight during the experimental period and average daily feed intake are presented in Figure 2.

Further, the weight of different organs of the animal was noted to calculate the organ weight ratio. As expected, the animal gained weight with time, but no difference in body weight and organ ratio was noted among the control and the bacteriophage treated groups. Similarly, organ weight data was compared with body weight, which was calculated in terms of percentage values of the organ to body weight. The organ to body weight ratio after the completion of the experimental period is presented in Table 1. No significant change in ratio was observed among the experimental group.

\section{Estimation of Hematological Parameters}

The level of RBC, WBC, lymphocytes, monocytes, eosinophils, neutrophils, $\mathrm{Hb}, \mathrm{PCV}, \mathrm{MCV}, \mathrm{MCH}, \mathrm{MCHC}$, and platelet count were analyzed in all the test groups (Table 2). The changes were nonsignificant, which suggested that continued bacteriophage therapy did not cause any changes in the blood profile. The reference range was compared according to Alemán et al., 1998. However, clinical 


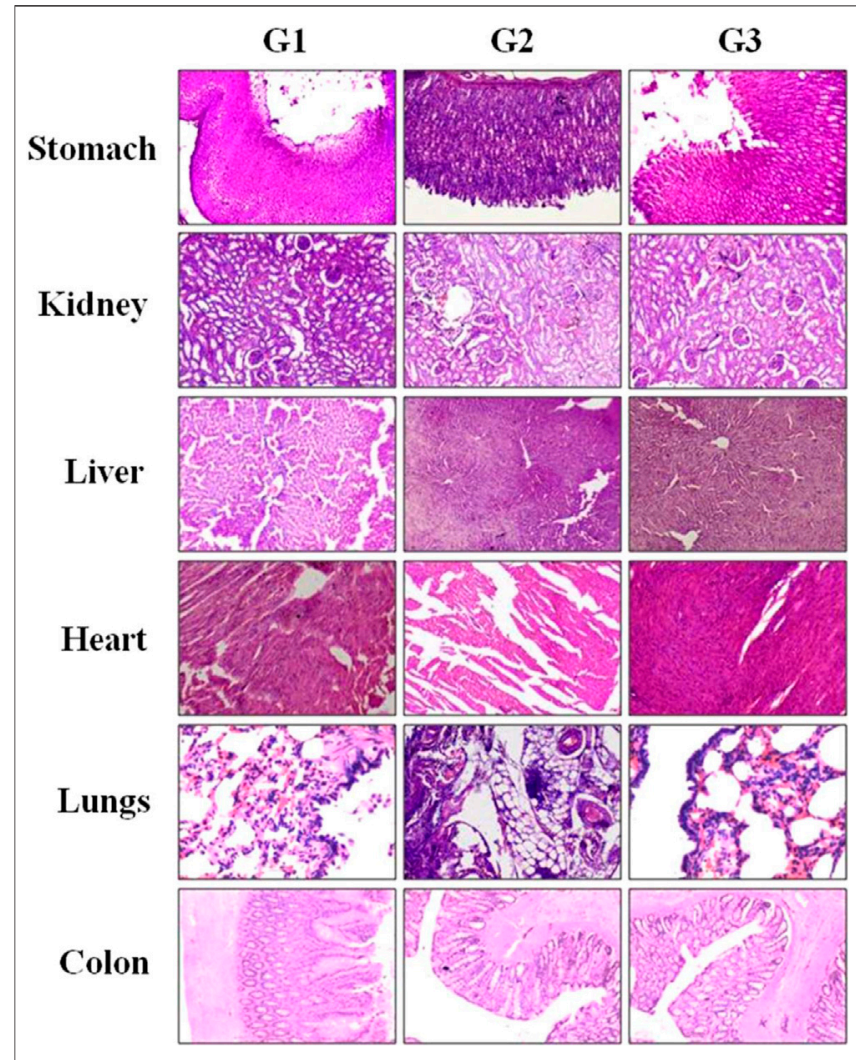

FIGURE 4 | Histopathological observation of major tissues obtained from GIT and other major organs of Charles Foster rats fed with (G1) vehicle control, (G2) medium-dose bacteriophages ( $\left.1 \times 10^{15} \mathrm{PFU} / \mathrm{ml}\right)$, and (G3) high dose of bacteriophages $\left(1 \times 10^{20} \mathrm{PFU} / \mathrm{ml}\right)$. Experimental animals were fed with phages for 28 days and were sacrificed. All the isolated tissues were fixed and stained with hematoxylin-eosin and observed under a microscope. laboratory parameters for rats were also considered in order to compare our data in different groups (Clinical Laboratory Parameters, 2021). In blood profile, levels of different types of leukocytes are considered to be the gross immunological biomarker.

\section{Estimation of Biochemical Parameters}

Biochemical parameters of all the animals were evaluated and compared to the healthy control group (Table 3). The biochemical parameters estimated were glucose, total cholesterol (TC), triglycerides (TG), high-density lipoprotein (HDL), lowdensity lipoprotein (LDL), very-low-density lipoprotein (VLDL), TB (total bilirubin), SGOT, SGPT, ALP, CK-MB, total protein (TP), albumin, globulin, $\mathrm{A} / \mathrm{G}$ ratio, creatinine, uric acid, blood urea, minerals, and important salts were also analyzed in all the three groups after the end of the study period. Hepatic, renal, lipid, and cardiac biomarkers analysis showed that oral bacteriophage using medium and high doses for 28 days did not alter the blood biochemistry.

\section{Estimation of Cytokines Level}

Interlukin-1 beta (IL-1 $\beta$ ), $\mathrm{L}-4, \mathrm{~L}-6$, and INF-gamma levels were estimated in all the animals and the test was performed using ELISA assay. The results of all the cytokines were compiled and graphically presented in Figure 3. The control group showed cytokine values of IL- 4 , IL- $1 \beta$, IL-6, and INF-gamma as $109.00 \pm$ $11.72,76.21 \pm 17.45,84.00 \pm 11.72$, and $53.33 \pm 13.74 \mathrm{pg} / \mathrm{ml}$, respectively. The cytokines assay results showed that pro-and anti-inflammatory level of cytokines varied but without statistically significant difference.

Histopathological Analysis

After the end of the experiment, tissue samples were collected, which were fixed and stained in order to examine any

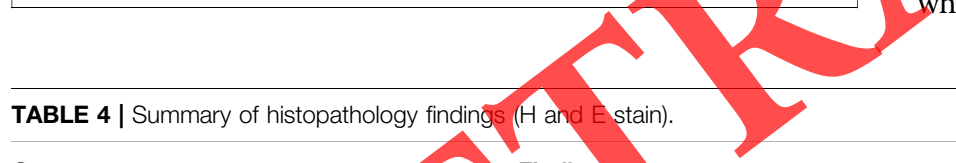

$\begin{array}{ll}\text { Organ } & \text { Mononuclear cell infiltration, multifocal } \\ \text { Lungs } & \text { Bronchitis, no alveolar lymph } \\ & \text { Normal and some enlarged alveoli, bronchopneumonia, multifocal } \\ \text { Heart } & \text { Accessory cortical nodule, focal, unilateral } \\ \text { Adrenals } & \text { Cortical vacuolation, diffuse, bilateral } \\ \text { Eyes } & \text { No abnormality detected } \\ \text { Liver } & \text { Mononuclear cell infiltration, focal } \\ \text { Spleen } & \text { Hepatocellular vacuolation, diffuse } \\ \text { Thymus } & \text { No abnormality detected } \\ \text { Kidneys } & \text { No abnormality detected } \\ \text { Testes } & \text { Mononuclear cell infiltration, multifocal } \\ \text { Stomach } & \text { Tubular degeneration, multi focal, bilateral } \\ \text { Duodenum } & \text { Tubular degeneration, focal, unilateral } \\ \text { Jejunum } & \text { Normal gastric mucosa, no necrosis } \\ \text { Ileum } & \text { No abnormality detected } \\ \text { Caecum } & \text { No abnormality detected } \\ \text { Rolon } & \text { No abnormality detected }\end{array}$

$\begin{array}{cccccc}\text { G1A1 } & \text { G1A4 } & \text { G2A1 } & \text { G2A4 } & \text { G3A1 } & \text { G3A4 } \\ 0 & 1 & 1 & 0 & 1 & 0 \\ 0 & 0 & 0 & 0 & 0 & 0 \\ 0 & 0 & 0 & 0 & 0 & 0 \\ 0 & 0 & 0 & 0 & 0 & 0 \\ 0 & 0 & 0 & 0 & 0 & 0 \\ 0 & 0 & 0 & 0 & 0 & 0 \\ 0 & 0 & 0 & 0 & 0 & 0 \\ 0 & 1 & 0 & 0 & 0 & 1 \\ 0 & 0 & 0 & 0 & 0 & 0 \\ 0 & 0 & 0 & 0 & 0 & 0 \\ 0 & 0 & 0 & 0 & 0 & 0 \\ 0 & 0 & 0 & 0 & 1 & 0 \\ 0 & 0 & 0 & 0 & 0 & 0 \\ 0 & 1 & 0 & 0 & 0 & 0 \\ 0 & 0 & 0 & 0 & 0 & 0 \\ 0 & 1 & 0 & 0 & 0 & 0 \\ 0 & 0 & 1 & 0 & 0 & 0 \\ 0 & 0 & 0 & 0 & 0 & 0 \\ 0 & 0 & 0 & 0 & 0 & 0 \\ 0 & 0 & 0 & 0 & 0 & 0 \\ 0 & 0 & 0 & 0 & 0 & 0 \\ 0 & 0 & 0 & 0 & 0 & 0 \\ 0 & 0 & 0 & 0 & 0 & 0\end{array}$


histopathological changes in all major organs. The changes were compiled using microscopic images as seen in Figure 4 and Table 4. The results depicted no notable significant changes in the GIT as well as other major organs as determined by a pathologist. Thus, no significant histopathological changes were observed in collected tissues after the experimental period suggesting safe bacteriophage therapy.

\section{DISCUSSION}

In the present study, we decided to explore the possibility of using oral bacteriophages at high concentration for many weeks to see the adverse/toxic and immunological effects in a rodent model. We divided adult Charles Foster rats into three groups: A group without intervention and two experimental groups given phage dosages of $10^{15} \mathrm{PFU} / \mathrm{ml}$ and $10^{20} \mathrm{PFU} / \mathrm{ml}$ daily for 28 days. Various parameters like behavioral changes, body weight, food and water intake, and organ to body weight ratio, hematological, biochemical, cytokines levels and histopathological changes were examined. It was intriguing to see that there were no significant changes in any of the parameters mentioned above as compared to the control group. Both the groups of rats with the medium and high dosages of phages exhibited a similar kind of response. The behavioural changes observed during the first $2 \mathrm{~h}$ might be due to discomfort and strange experience due to gavage procedure. This speculation is further proved as no such response could be noted during subsequent bacteriophage dosages given in the same way. The absence of lethality after phage administration indicates that oral phage therapy is safe and free of toxicity. Sulakvelidze et al. (2001) also have observed that doses between $10^{5}$ and $10^{11}$ through oral, rectal, topical and respiratory routes did not cause a visible adverse effect. When Bogovazova et al. (1991) and Bogovazova et al. (1992) adninistered bacteriophage specific to Klebsiella spp. through intramuscular, intraperitoneal and intravenous in rats and guinea pigs to study the pharmacokinetics and toxicology of the phages, no acute toxicity, macroscopic or microscopic changes could be noticed (Bogovazora et al., 1991, Bogovazova et al., 1992). The observation was made even though the doses given were 3500 times higher than those projected for humans. In the continuation, this group performed another study and demonstrated that human patients infected with Klebsiella $s p p$. given specific bacteriophage were not associated with any toxicity.

It is interesting to see that the total and differential leukocyte counts remain unaffected indicating absence of induction of inflammatory response against the fed bacteriophages. It is intriguing to see that pro-inflammatory (IL-1 $\beta$, IL4, and IL6) cytokines were not altered despite such a high dose of bacteriophage (Górski et al., 2012; Hong et al., 2016; Van Belleghem et al., 2018). IL4 leading to suppression of TH1 response could also be negated as no significant change was be seen. IFN $\gamma$ is also known as type II interferon that has a critical role both in innate and adaptive immunity against viral, some bacterial and protozoal infections. IFN $\gamma$ is known to inhibit viral replication directly. The indifference in the levels of IFN $\gamma$ in the experimental group than the control group suggests that bacteriophages given orally failed to induce the overproduction of IFN $\gamma$. The scientific data suggested that any form of the pathogen should initiate the first immune response as inflammation (Belkaid and Hand, 2014). Sensitized cells result in the production and release of proinflammatory cytokines, which helps the immune system to repel the incoming pathogens such as pathogenic bacteria and viruses (Ganesh et al., 2013; McCarthy et al., 2013). In support of the present study, the earlier report states a minimal alteration in the serum cytokine levels when T4 bacteriophages were administered orally (Miernikiewicz et al., 2013). Hong et al. have shown that at times phage treated rats had lower cytokine level as compared to controls (Hong et al., 2016). Thus, therapeutic feeding of bacteriophages targeting any gut bacterial pathogen implicated induces either minimal or no adverse effect. Even though oral administration of phages was given for 4 weeks, it did not cause a significant immunological response. The possible explanations for this observation may those phages are the part of normal microbiota/virobiota of humans and therefore not eliciting the significant detrimental immune responses. In support of the above statement there are many reports suggesting that the phages may be the part of human microbiota (Miot et al., 2011; Navarro and Muniesa, 2017; and; Van Belleghem et al., 2019). It was also found that against $\mathrm{T}$-like bacteriophages, natural antibodies may be presented due to it's natural existence as a part of normal flora (Dabrowska et al., 2014). Eusiak-Szelachowska et al. 2014 has reported minimal altered immune response as the outcome of the phage therapy was not affected by the appearance of neutralizing antibodies. However, exact mechanism of antiphage cellular response is yet to be demonstrated. The other possibility is that high oral bacteriophages might cause desensitization or immune paralysis resulting in all the immunological parameters in normal range. If this is the case, this immune paralysis phenomenon will be quite useful in cases where prolong bacteriophage therapy is warranted.

Therefore, it seems that oral bacteriophage therapy is safe, and it can be used to eradicate the specific pathogen present in the gut. However, it would have been better if the effect of oral phage therapy on alteration of gut microbiota was also evaluated. Further, one must study to explore whether phage genes/ genome is getting integrated into the genome of host bacteria or other related bacteria to convince the regulatory authority. The literature available in this field is still scarce and contradictory, and there is a need to make desperate attempts to make more indepth investigations.

\section{CONCLUSION}

Thus, in the conclusion of the above-detailed toxicity and immunobiological activity of medium and high oral administration of bacteriophages of XDR Klebsiella pneumoniae, the therapeutic feeding of bacteriophages suggesting no adverse effect was found when animals were challenged at high PFU count $\left(1 \times 10^{20} / \mathrm{ml}\right)$. Continued phage therapy for 28 days was found to be safe with respect to animal hematology, biochemistry, body 
weight, feed intake, histopathology, and vital behavioral parameters. Besides, the immunological response of the animal after the experimental period was found safe with minimal change in pro and anti-inflammatory level of cytokines, indicating that the oral administration of bacteriophages would appear to be a safe practice for fighting against XDR or any other bacterial pathogens and no adverse acute immune response was noted during the study period.

\section{DATA AVAILABILITY STATEMENT}

The original contributions presented in the study are included in the article/Supplementary Material, further inquiries can be directed to the corresponding author.

\section{ETHICS STATEMENT}

The animal study was reviewed and approved by Central Animal House (Reg.no.542/02/ab/CPCSEA), Institute of Medical Sciences, Banaras Hindu University, Varanasi, India.

\section{REFERENCES}

Alemán, C. L., Más, R. M., Rodeiro, I., Noa, M, Hernández, C, Menéndez, R, et al. (1998). Reference database of the main physiological parameters in SpragueDawley rats from 6 to 32 months. Lab. Anim. 32, 457-466. doi:10.1258/ 002367798780599802

Belkaid, Y., and Hand, T. W. (2014). Role of the microbiota in immunity and inflammation. Cell 157 (1), 121-141. doi:10.1016/j.cell.2014.03.011

Bogovazova, G. G., Voroshilova, N. N., and Bondarenko, V M. (1991). [The efficacy of Klebsiella pneumoniae bacteriophage in the therapy of experimental Klebsiella infection]. Zh. Mikrobiol. Epidemiol. Immunobiol. 4, 5-8.

Bogovazova, G. G., Voroshilova, N. N., Bondarenko, V. M., Gorbatkova, G. A., Afanas'eva, E. V., Kazakova, T. B., et al. (1992). [Immunobiological properties and therapeutic effectiveness of preparations from Klebsiella bacteriophages]. Zh. Mikrobiol. Epidemiol. Immunobiol, 30-33.

Botham, P. A. (2002). Acute systemic toxicity. ILAR J. 43 Suppl (Suppl. 1_1), S27-S30. doi:10.1093/ilar.43.suppl

Capparelli, R., Parlato, M., Borriello, G., Salvatore, P., and Iannelli, D. (2007). Experimental phage therapy against Staphylococcus aureus in mice. Antimicrob. Agents Chemother. 51, 2765-2773. doi:10.1128/aac.01513-06

Chaturvedi, A., and Nath, G. (2018). Oraladministration of Klebsiella pneumoniaespecific bacteriophage eradicates the bacteria in albino mice. Indian J. Med. Microbiol. 36, 293-294. doi:10_4103/ijmm.ijmm_18_154

Clinical Laboratory Parameters (2021). Clinical laboratory parameters for Crl: WI(Han) rats - Charles river. Available at: http://www.criver.com/sites/default/ files/resources/rm_rm_r_Wistar_Han_clin_lab_parameters_08.pdf (Accessed Feb 11th, 2021).

Dabrowska, K., Miernikiewicz, P., Piotrowicz, A., Hodyra, K., Owczarek, B., Lecion, D., et al. (2014). Immunogenicity studies of proteins forming the T4 phage head surface. J. Virol. 88 (21), 12551-12557. doi:10.1128/jvi.02043-14

de Jong, M. D., Simmons, C. P., Thanh, T. T., Hien, V. M., Smith, G. J. D., Chau, T. N. B., et al. (2006). Fatal outcome of human influenza A (H5N1) is associated with high viral load and hypercytokinemia. Nat. Med. 12 (10), 1203-1207. doi:10.1038/nm1477

Debarbieux, L., Leduc, D., Maura, D., Morello, E., Criscuolo, A., Grossi, O., et al. (2010). Bacteriophages can treat and PreventPseudomonas aeruginosaLung infections. J. Infect. Dis. 201 (7), 1096-1104. doi:10.1086/651135

Ganesh, B. P., Klopfleisch, R., Loh, G., and Blaut, M. (2013). Commensal Akkermansia muciniphila exacerbates gut inflammation in Salmonella

\section{AUTHOR CONTRIBUTIONS}

MG and GN designed the experiment. MG, SR, DS, AS, DK, and SK performed animal experimental procedures, detailed test methodology, and data analysis. MG and AS was the major contributor in writing the manuscript. GN reviewed, modified and finalized the final data and text representation. ND was involved in histopathological analysis of all the tissues and reporting. All authors read and approved the final manuscript.

\section{ACKNOWLEDGMENTS}

Authors gratefully acknowledged the support provided by Department of Health Research under the Ministry of Health and Family Welfare (Government of India), New Delhi, India and Indian Council of Medical Research (ICMR) in the form of establishment of State Level Viral Research and Diagnostic Laboratory (VRDL) network under scheme 5066. Authors gratefully acknowledge the help provided by T.B. Singh, Professor of Biostatistics, Institute of Medical sciences, Banaras Hindu University for the biostatistical analysis of the data.

Ganeshan, S. D., and Hosseinidoust, Z. (2019). Phage therapy with a focus on the human microbiota. Antibiotics 8 (3), 131. doi:10.3390/antibiotics8030131

Gavel, P., Bharti, S., Nath, G., and Srivastava, R. (2019). A genomic study of Salmonella Typhi "Vi" specific bacteriophages: futuristic approach in therapeutics. J. Clin. Diagn. Res. 13 (10), BC14-BC17. doi:10.7860/JCDR/ 2019/42189.13252

rski, A. Kniotek, M., Perkowska-Ptasińska, A., Mróz, A., Przerwa, A., Gorczyca, W, et al. (2006). Bacteriophages and transplantation tolerance. Transplant. Proc. 38 (1), 331-333. doi:10.1016/j.transproceed.2005.12.073

Górski, A., Międzybrodzki, R., Borysowski, J., Dąbrowska, K., Wierzbicki, P., Ohams, M., et al. (2012). Phage as a modulator of immune responses. Adv. Virus. Res. 83, 41-71. doi:10.1016/b978-0-12-394438-2.00002-5

Górski, A., and Weber-Dabrowska, B. (2005). The potential role of endogenous bacteriophages in controlling invading pathogens. Cell. Mol. Life Sci. 62, 511-519. doi:10.1007/s00018-004-4403-6

Gupta, P., Malik, A., Saraf, S. K., and Nath, G. (2016). Bacteriophage therapy of methicillin resistant Staphylococcus aureus biofilms on orthopaedic implants in rabbit model. BAOJ Orthop 1, 004. doi:10.24947/baojort/1/1/104

Gupta, P., Singh, H. S., Shukla, V. K., Nath, G., and Bhartiya, S. K. (2019). Bacteriophage therapy of chronic nonhealing wound: clinical study. Int. J. Lower Extrem. Wounds 18 (2), 171-175. doi:10.1177/1534734619835115

Hong, Y., Thimmapuram, J., Zhang, J., Collings, C. K., Bhide, K., Schmidt, K., et al. (2016). The impact of orally administered phages on host immune response and surrounding microbial communities. Bacteriophage 6 (3), e1211066. doi:10. 1080/21597081.2016.1211066

Huff, W. E., Huff, G. R., Rath, N. C., Balog, J. M., and Donoghue, A. M. (2005). Alternatives to antibiotics: utilization of bacteriophage to treat colibacillosis and prevent foodborne pathogens. Poult. Sci. 84, 655-659. doi:10.1093/ps/84.4.655

Institóris, L., Siroki, O., Dési, I., Lesznyák, J., Serényi, P., Szekeres, É., et al. (1998). Extension of the protocol of OECD guideline 407 (28-day repeated dose oral toxicity test in the rat) to detect potential immunotoxicity of chemicals. Hum. Exp. Toxicol. 17 (4), 206-211. doi:10.1177/096032719801700402

Kishor, C., Mishra, R. R., Saraf, S. K., Kumar, M., Srivastav, A. K., and Nath, G. (2016). Phage therapy of staphylococcal chronic osteomyelitis in experimental animal model. Indian J. Med. Res. 143, 87-94. doi:10.4103/0971-5916.178615

Kropinski, A. M., Mazzocco, A., Waddell, T. E., Lingohr, E., and Johnson, R. P. (2009). Enumeration of bacteriophages by double agar overlay plaque assay. Methods Mol Biol. 501, 69-76. doi:10.1007/978-1-60327-164-6_7 
Luepke, K. H., Suda, K. J., Boucher, H., Russo, R. L., Bonney, M. W., Hunt, T. D., et al. (2017). Past, present, and future of antibacterial economics: increasing bacterial resistance, limited antibiotic pipeline, and societal implications. Pharmacotherapy 37, 71-84. doi:10.1002/phar.1868

Łusiak-Szelachowska, M., Zaczek, M., Weber-Dąbrowska, B., Międzybrodzki, R., Kłak, M., Fortuna, W., et al. (2014). Phage neutralization by sera of patients receiving phage therapy. Viral Immunol. 27 (6), 295-304. doi:10.1089/vim. 2013.0128

Mann, N. H. (2008). The potential of phages to prevent MRSA infections. Res. Microbiol. 159 (5), 400-405. doi:10.1016/j.resmic.2008.04.003

McCarthy, M. K., Levine, R. E., Procario, M. C., McDonnell, P. J., Zhu, L., Mancuso, P., et al. (2013). Prostaglandin E2 induction during mouse adenovirus type 1 respiratory infection regulates inflammatory mediator generation but does not affect viral pathogenesis. PLoS One 8, e77628. doi:10.1371/journal.pone. 0077628

Miernikiewicz, P., Dąbrowska, K., Piotrowicz, A., Owczarek, B., Wojas-Turek, J., Kicielińska, J., et al. (2013). T4 phage and its head surface proteins do not stimulate inflammatory mediator production. PLoS One 8, e71036. doi:10.1371/ journal.pone.0071036

Minot, S., Sinha, R., Chen, J., Li, H., Keilbaugh, S. A., Wu, G. D., et al. (2011). The human gut virome: inter-individual variation and dynamic response to diet. Genome Res. 21 (10), 1616-1625. doi:10.1101/gr.122705.111

Mishra, R. R., and Nath, G. (2020). Detection of bacteriophages against eskape group of nosocomial pathogens from ganga river water during community bath at various rituals: since 2013-2019. J. App Pharm. Sci. Res. 3 (1), 17-21. doi:10. 31069/japsr.v3i1.5

Mogensen, T. H., and Paludan, S. R. (2001). Molecular pathways in virus-induced cytokine production. Microbiol. Mol. Biol. Rev. 65 (1), 131-150. doi:10.1128/ mmbr.65.1.131-150.2001

Morgan, X. C., Tickle, T. L., Sokol, H., Gevers, D., Devaney, K. L., Ward, D. V., et al. (2012). Dysfunction of the intestinal microbiome in inflammatory bowel disease and treatment. Genome Biol. 13, R79. doi:10.1186/gb-2012-13-9-r79

Nasukawa, T., Uchiyama, J., Taharaguchi, S., Ota, S., Ujihara, T., Matsuzaki, S., et al. (2017). Virus purification by $\mathrm{CsCl}$ density gradient using general centrifugation. Arch. Virol. 162, 3523-3528. doi:10.1007/s00705-017-3513-Z

Nath, G., Janam, R., Kumar, R., and Gangwar, M. (2019). Bacteriophage therapy an alternative to antibiotics-an experimental study in mice. Ann. Natl. Acad. Med. Sci. (India) 55 (03), 151-158. doi:10.1055/s-0039-1698545

Navarro, F., and Muniesa, M. (2017). Phages in the human body. Front. Microbiol. 8, 566. doi:10.3389/fmicb.2017.00566

Patel, D. R., Bhartiya, S. K., Kumar, R., Shukla, V. K., and Nath, G. (2019). Use of customized bacteriophages in the treatment of chronic nonhealing wounds: a

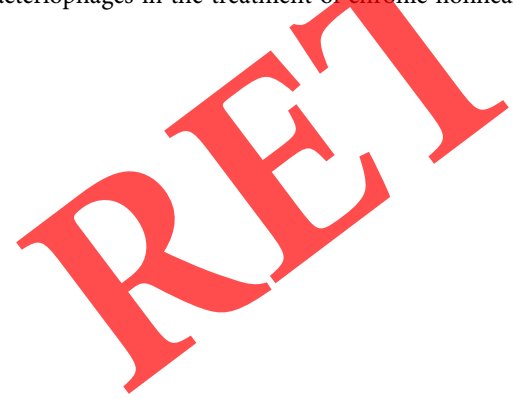

prospective study. Int. J. Lower Extremity Wounds 20, 36-47. doi:10.1177/ 1534734619881076

Rajpal, D. K., and Brown, J. R. (2013). Modulating the human gut microbiome as an emerging therapeutic paradigm. Sci. Prog. 96 (3), 224-236. doi:10.3184/ $003685013 \times 13691404141587$

Rouse, M. D., Stanbro, J., Roman, J. A., Lipinski, M. A., Jacobs, A., Biswas, B., et al. (2020). Impact of frequent administration of bacteriophage on therapeutic efficacy in an A. bauma nnii mouse wound infection model. Front. Microbiol. 11, 414. doi:10.3389/fmicb.2020.00414

Sulakvelidze, A., Alavidze, Z., and Morris, J. G., Jr. (2001). Bacteriophage therapy. Antimicrob. Agents Chemother. 45, 649-659. doi:10.1128/aac.45.3.649-659.2001

Szermer-Olearnik, B., and Boratyński, J. (2015). Removal of endotoxins from bacteriophage preparations by extraction with organic solvents. PLoS One 10 (3), e0122672. doi:10.1371/journal.pone.0122672

Tayebeh, F., Amani, J., Nazarian, S., Moradyar, M., and Mirhosseini, S. A. (2016). Molecular diagnosis of clinically isolated Klebsiella pneumoniae strains by PCRELISA. J. Appl. Biotechnol. Rep. 3 (4), 501-505.

Thannickal, V. J., and Fanburg, B. L. (2000). Reactive oxygen species in cell signaling. Am. J. Physiology-Lung Cell Mol. Physiol. 279 (6), L1005-L1028. doi:10.1152/ajplung.2000.279.6.11005

Van Belleghem, J., Dąbrowska, K., Vaneechoutte, M., Barr, J., and Bollyky, P. (2018). Interactions between bacteriophage, bacteria, and the mammalian immune system. Viruses 11 (1), 10. doi:10.3390/v11010010

Van Belleghem, J., Dąbrowska, K., Vaneechoutte, M., Barr, J., and Bollyky, P. (2019). Interactions between bacteriophage, bacteria, and the mammalian immune system. Viruses 11 (1), 10. doi:10.3390/v11010010

Zumla, A., Rao, M., Wallis, R. S., Kaufmann, S. H. E., Rustomjee, R., Mwaba, P., et al. (2016). Host-directed therapies for infectious diseases: current status, recent progress, and future prospects. Lancet Infect. Dis. 16, e47-e63. doi:10. 1016/s1473-3099(16)00078-5

Conflict of Interest: The authors declare that the research was conducted in the absence of any commercial or financial relationships that could be construed as a potential conflict of interest.

Copyright (c) 2021 Gangwar, Rastogi, Singh, Shukla, Dhameja, Kumar, Kumar and Nath. This is an open-access article distributed under the terms of the Creative Commons Attribution License (CC BY). The use, distribution or reproduction in other forums is permitted, provided the original author(s) and the copyright owner(s) are credited and that the original publication in this journal is cited, in accordance with accepted academic practice. No use, distribution or reproduction is permitted which does not comply with these terms. 